

Open Access

Asian Australas. J. Anim. Sci.

Vol. 27, No. 9 : 1285-1292 September 2014

http://dx.doi.org/10.5713/ajas.2013.13742

www.ajas.info

pISSN $1011-2367$ elSSN 1976-5517

\title{
Effects of Aspergillus Oryzae Culture and 2-Hydroxy-4-(Methylthio)-Butanoic Acid on In vitro Rumen Fermentation and Microbial Populations between Different Roughage Sources
}

\author{
H. Sun ${ }^{1,2}$, Y. M. Wu ${ }^{1, *}$, Y. M. Wang ${ }^{3}$, J. X. Liu ${ }^{1, *}$, and K. H. Myung ${ }^{4}$ \\ ${ }^{1}$ Institute of Dairy Science, College of Animal Sciences, Zhejiang University, Hangzhou, 310058, China
}

\begin{abstract}
An in vitro experiment was conducted to evaluate the effects of Aspergillus oryzae culture (AOC) and 2-hydroxy-4(methylthio)-butanoic acid (HMB) on rumen fermentation and microbial populations between different roughage sources. Two roughage sources (Chinese wild rye [CWR] vs corn silage [CS]) were assigned in a $2 \times 3$ factorial arrangement with $\mathrm{HMB}(0 \mathrm{or} 15 \mathrm{mg})$ and AOC $(0,3$, or $6 \mathrm{mg})$. Gas production (GP), microbial protein (MCP) and total volatile fatty acid (VFA) were increased in response to addition of HMB and AOC $(\mathrm{p}<0.01)$ for the two roughages. The HMB and AOC showed inconsistent effects on ammonia-N with different substrates. For CWR, neither HMB nor AOC had significant effect on molar proportion of individual VFA. For CS, acetate was increased $(\mathrm{p}=0.02)$ and butyrate was decreased $(\mathrm{p}<0.01)$ by adding HMB and AOC. Increase of propionate was only occurred with AOC $(\mathrm{p}<0.01)$. Populations of protozoa $(\mathrm{p} \leq 0.03)$ and fungi $(\mathrm{p} \leq 0.02)$ of CWR were differently influenced by HMB and AOC. Percentages of $F$. succinogenes, $R$. albus, and $R$. flavefaciens $(\mathrm{p}<0.01)$ increased when AOC was added to CWR. For CS, HMB decreased the protozoa population $(\mathrm{p}=0.01)$ and increased the populations of $F$. succinogenes and $R$. albus $(\mathrm{p} \leq 0.03)$. Populations of fungi, $F$. succinogenes $(\mathrm{p}=0.02)$ and $R$. flavefacien $(\mathrm{p}=0.03)$ were increased by adding AOC. The HMB $\times$ AOC interactions were noted in MCP, fungi and $R$. flavefacien for CWR and GP, ammonia-N, MCP, total VFA, propionate, acetate/propionate (A/P) and $R$. albus for CS. It is inferred that addition of HMB and AOC could influence rumen fermentation of forages by increasing the number of rumen microbes. (Key Words: Aspergillus Oryzae, 2-Hydroxy-4-(Methylthio)-Butanoic Acid, Chinese Wild Rye, Corn Silage, In vitro Rumen Fermentation, Microbial Population)
\end{abstract}

\section{INTRODUCTION}

Chinese wild rye (CWR) and corn silage (CS) are major roughages which are commonly fed to cattle in China's dairy farms. However, the conversion efficiency of roughages to meat and milk is limited by low digestibility of roughage cell walls and low yield of microbial protein in the rumen (Wang and McAllister, 2002). Therefore, it is

\footnotetext{
* Corresponding Authors: Y. M. Wu. Tel: +86-571-88982930, Fax: +86-571-88982930, E-mail: ymwu@zju.edu.cn / J. X. Liu. E-mail: liujx@zju.edu.cn

${ }^{2}$ Qilu University of Technology, Jinan, 250353, China.

${ }^{3}$ Novus International Research Center, Beijing, 100085, China.

${ }^{4}$ Department of Animal Science, Chonnam National University, Gwangju 500-757, Korea.

Submitted Nov. 22, 2013; Revised Jan. 2, 2014; Accepted Jan. 31, 2014
}

important to improve fiber digestibility and microbial protein synthesis for achieving greater feed utilization and animal production. The use of Aspergillus oryzae culture (AOC) increased digestion of feedstuffs mainly through improved rumen fiber degradation (Chen et al., 2004; Di Francia et al., 2008). However, AOC had variable effect on different roughages, and had no significant improvement on CS (Beharka and Nagaraja, 1993).

Rumen-protected Met, 2-hydroxy-4-(methylthio)butanoic acid (HMB) is a source of L-Met which is commonly used in ruminant feeds, because Met has been considered as the limiting amino acid for high producing dairy cattle diets (NRC, 2001). Nevertheless, HMB does not totally escape rumen microbial metabolism and can be a source of Met for rumen microorganisms. However, the impact of HMB on rumen fermentation seems highly 
variable and remains unclear. Although addition of HMB improved microbial protein synthesis (Vázquez-Añón et al., 2001), some researchers found no changes in volatile fatty acid (VFA) proportions by HMB (Vázquez-Añón et al., 2001; Wilson et al., 2008), whereas others reported changes in VFA profile (Noftsger et al., 2003; Chung et al., 2006). In addition, the mechanisms by which HMB could impact microbial digestion in the rumen are not yet clear.

Supplementing AOC can enhance utilization of fiber, and adding $\mathrm{HMB}$ probably supplies Met and balances the amino acids to improve protein utilization in the rumen. It is well-known that fiber and protein are very important nutrients for ruminants. The simultaneous enhanced utilization of fiber and protein with supplementation of AOC and HMB may achieve a synergistic improvement in rumen functions. So a trial was conducted in which both AOC and HMB were allocated simultaneously as supplementations to enhance rumen function. For this purpose, we used an in vitro experiment to evaluate the effects of $\mathrm{AOC}$ and $\mathrm{HMB}$ on rumen fermentation and microbial populations in two different roughage sources (CWR and CS).

\section{MATERIALS AND METHODS}

\section{Experimental design}

Two kinds of roughages (CWR vs CS) were used as roughage substrates. They were analyzed for dry matter (DM), crude protein (CP), ash (AOAC, 1997), neutral detergent fiber (NDF) and acid detergent fiber (ADF) expressed inclusive of residual ash (Van Soest et al., 1991). Chemical composition of the two roughages is presented in Table 1. Each roughage substrate was assigned to all the treatments in a $2 \times 3$ factorial arrangement with $\mathrm{AOC}$ and HMB as main effects. The AOC (Amaferm, Biozyme, Inc., St. Joseph, MO, USA), was added into substrates at the level of 0,3 , or $6 \mathrm{mg}$. The HMB (MFP, Novus Int. Inc. St. Louis, MO, USA), was added into substrates at the level of 0 or $15 \mathrm{mg}$ together with AOC. The treatments included: control (no AOC or HMB), AOC group without HMB (3 $\mathrm{mg}$ or $6 \mathrm{mg})$, HMB group without AOC (15 mg) and AOC plus HMB group ( $3 \mathrm{mg} \mathrm{AOC}+15 \mathrm{mg} \mathrm{HMB}$; $6 \mathrm{mg} \mathrm{AOC}+15$

Table 1. Chemical composition of two roughages (DM basis)

\begin{tabular}{lcc}
\hline \multirow{2}{*}{ Nutrients } & \multicolumn{2}{c}{ Roughage sources } \\
\cline { 2 - 3 } & Chinese wild rye & Corn silage \\
\hline DM & 90.70 & 92.76 \\
OM & 95.02 & 92.16 \\
CP & 7.14 & 9.84 \\
NDF & 64.34 & 55.02 \\
ADF & 37.87 & 32.87 \\
\hline
\end{tabular}

DM, dry matter; OM, organic matter; $\mathrm{CP}$, crude protein; NDF, neutral detergent fiber expressed inclusive of residual ash; ADF, acid detergent fiber expressed inclusive of residual ash. mg HMB). Each treatment was performed in triplicate.

\section{In vitro gas test procedure}

The substrates in the in vitro test consisted of finely ground corn $(100 \mathrm{mg})$ and one kind of roughage $(100 \mathrm{mg})$, CWR or CS. The gas production (GP) was determined according to the method of Menke and Steingass (1988). Rumen fluids were collected before morning feeding from three rumen-fistulated cows fed twice daily on a mixed diet. Ingredients and chemical composition (\% DM) of the diet are shown in Table 2.

Rumen fluid was strained through four layers of gauze into a pre-warmed syringes flushed with $\mathrm{CO}_{2}$ at $39^{\circ} \mathrm{C}$. Syringes were filled with $30 \mathrm{~mL}$ medium consisting of 10 $\mathrm{mL}$ rumen fluid and $20 \mathrm{~mL}$ artificial saliva. The syringes were incubated in a water bath $\left(39^{\circ} \mathrm{C}\right)$ for $24 \mathrm{~h}$. The GP in vitro was recorded at $3,6,9,12$, and $24 \mathrm{~h}$ incubation times.

\section{Sampling and measurement}

The incubation was stopped at $24 \mathrm{~h}$ fermentation and the $\mathrm{pH}$ of rumen liquor was determined immediately using a $\mathrm{pH}$ meter (S40 SevenMulti, Mettler Toledo, Shanghai, China). The incubated inoculants were used for analysis of ammonia-N, VFA, microbial protein (MCP) and microbial communities. Ammonia-N, VFA and MCP concentrations

Table 2. Diet ingredients and chemical composition for the rumen fistulated cows

\begin{tabular}{lc}
\hline Item & $\%$ DM \\
\hline Ingredients & 27.00 \\
Corn & 5.00 \\
Wheat bran & 5.00 \\
Soybean meal & 4.00 \\
Cottonseed meal & 17.00 \\
Corn silage & 10.00 \\
Chinese wild rye & 28.00 \\
Alfalfa hay & 0.25 \\
Calcium carbonate & 1.25 \\
Calcium hydrogen phosphate & 1.00 \\
Calcium hydrogen carbonate & 0.50 \\
Salt & 0.10 \\
Premix ${ }^{1}$ & \\
Calculated nutrition composition & 6.52 \\
NE & $(\mathrm{MJ} / \mathrm{kg}$ DM) \\
CP & 1.51 \\
NDF & 34.40 \\
ADF & 2.21 \\
Calcium & 0.92 \\
Phosphorus & 0.62 \\
\hline
\end{tabular}

$\mathrm{DM}$, dry matter; $\mathrm{NE}_{\mathrm{L}}$, net energy for lactation; $\mathrm{CP}$, crude protein; $\mathrm{NDF}$, neutral detergent fiber expressed inclusive of residual ash; ADF, acid detergent fiber expressed inclusive of residual ash.

${ }^{1}$ Formulated to provide (per kg of DM): vitamin A, 600,000 IU; vitamin $\mathrm{D}_{3}, 150,000 \mathrm{IU}$; vitamin E, 3,000 IU; Fe, 1,500 mg; Cu, 1,500 mg; Zn, 7,500 mg; Se, $50 \mathrm{mg}$; I, $90 \mathrm{mg}$; Co, $20 \mathrm{mg}$. 
were determined using methods of $\mathrm{Hu}$ et al. (2005).

Total DNA was isolated using a genomic DNA kit (Axygen Biosciences, Union City, CA, USA) following the manufacturer's instructions. The amplifying primer sets of total bacteria, protozoa, fungi, $F$. succinogenes, $R$. flavefaciens and $R$. albus were designed as described by Denman and McSweeney (2006), Denman et al. (2007), and Koike and Kobayashi (2001), respectively as in Table 3. The species-specific real-time qPCR was performed using the ABI 7500 real time PCR system (Applied Biosystems, Foster City, CA, USA) with fluorescence detection of SYBR green dye. Samples were run under the amplification conditions as described by Mao et al. (2010).

\section{Calculations and statistical analysis}

To describe the dynamics of GP over time, the following equation (Ørskov and McDonald, 1979) was chosen:

$$
\mathrm{GP}=\mathrm{a}+\mathrm{b}\left(1-\mathrm{e}^{-\mathrm{ct}}\right)
$$

where, GP = cumulative $\mathrm{GP}(\mathrm{mL})$ at $\mathrm{t}$ time, $\mathrm{t}=$ incubation time $(\mathrm{h}), \mathrm{a}=$ the gas production from immediately soluble fraction $(\mathrm{mL}), \mathrm{b}=$ the gas production from immediately insoluble fraction $(\mathrm{mL}),(\mathrm{a}+\mathrm{b})=$ potential GP $(\mathrm{mL}), \mathrm{c}=$ rate constant of GP $(\% / \mathrm{h})$, and $\mathrm{a}, \mathrm{b}$ and $\mathrm{c}$ are constants.

The following equation of Menke and Steingass (1988) was used to calculate the in vitro organic matter digestibility (IVOMD):

$$
\operatorname{IVOMD}(\%)=0.986 \mathrm{GP}+0.0606 \mathrm{CP}+11.03
$$

where, $\mathrm{GP}=$ cumulative $\mathrm{GP}(\mathrm{mL})$ at $24 \mathrm{~h}, \mathrm{CP}=$ crude protein content of substrates $(\mathrm{g} / \mathrm{kg})$.

Populations of protozoa, fungi, $F$. succinogenes, $R$. albus, and $R$. flavefaciens, were expressed as a proportion of total rumen bacterial $16 \mathrm{~S}$ rDNA according to the equation of Chen et al. (2008):

Relative quantification $=2^{-(\mathrm{Ct} \text { target }-\mathrm{Ct} \text { total bacteria })}$

where, Ct represented threshold cycle.

All of the statistical analyses were conducted using the general linear models (GLM) procedures of SAS software (SAS Institute, 1999). Data from CWR and CS were analyzed separately as a completely randomized design with $\mathrm{HMB}, \mathrm{AOC}$ and their interaction included. Effect of AOC supplementation was determined by the "contrast" option of the GLM procedure. When this effect was significant $(\mathrm{p}<0.05)$, orthogonal polynomial (ORPOLY) contrasts using contrast coefficients that were obtained by ORPOLY macro were used to determine linear and quadratic responses to the concentrations of the AOC treatment. Significance was declared at $\mathrm{p}<0.05$.

\section{RESULTS}

\section{In vitro gas production and microbial protein}

In vitro rumen GP, ammonia-N and $\mathrm{MCP}$ at $24 \mathrm{~h}$ incubation with substrates of CWR and CS are given in Table 4.

Chinese wild rye: The addition of AOC and HMB had no significant effect on rumen $\mathrm{pH}(\mathrm{p}>0.05)$. Supplementing HMB significantly increased GP, c, IVOMD and MCP ( $\mathrm{p}<$ 0.01). Ammonia-N was markedly decreased by adding HMB ( $p=0.02)$. Addition of AOC influenced GP, IVOMD and MCP (linear, $\mathrm{p}<0.01$; quadratic, $\mathrm{p}<0.01$ ) and $\mathrm{c}$ (linear, $\mathrm{p}<0.01)$. The $\mathrm{HMB} \times \mathrm{AOC}$ interactions were noted in $\mathrm{MCP}$ $(\mathrm{p}<0.01)$.

Corn silage: GP, IVOMD, and MCP were increased $(\mathrm{p} \leq 0.02)$ in response to HMB addition (Table 4). However, adding HMB decreased $\mathrm{c}$ and ammonia-N $(\mathrm{p} \leq 0.02)$. The GP and IVOMD (linear, $\mathrm{p}<0.01$ ), c (linear, $\mathrm{p}<0.01$; quadratic, $\mathrm{p}$

Table 3. PCR primers for real-time PCR assay

\begin{tabular}{lcl}
\hline Target species $^{1}$ & Forward & \multicolumn{1}{c}{ Primer sequence } \\
\hline Total bacteria $^{1}$ & $\mathrm{~F}$ & CGGCAACGAGCGCAACCC \\
& $\mathrm{R}$ & CCATTGTAGCACGTGTGTAGCC \\
Fungi $^{1}$ & $\mathrm{~F}$ & GAGGAAGTAAAAGTCGTAACAAGGTTTC \\
& $\mathrm{R}$ & CAAATTCACAAAGGGTAGGATGATT \\
R. flavefaciens $^{1}$ & $\mathrm{~F}$ & CGAACGGAGATAATTTGAGTTACTTAGG \\
& $\mathrm{R}$ & CGGTCTCTGTATGTTATGAGGTATTACC \\
F. succinogenes $^{1}$ & $\mathrm{~F}$ & GTTCGGAATTACTGGGCGTAAA \\
& $\mathrm{R}$ & CGCCTGCCCCTGAACTATC \\
Protozoa $^{2}$ & $\mathrm{~F}$ & GCTTTCGWTGGTAGTGTATT \\
& $\mathrm{R}$ & CTTGCCCTCYAATCGTWCT \\
R. albus $^{3}$ & $\mathrm{~F}$ & CCCTAAAAGCAGTCTTAGTTCG \\
& $\mathrm{R}$ & CCTCCTTGCGGTTAGAACA \\
\hline
\end{tabular}

PCR, polymerase chain reaction.

${ }^{1}$ Denman and McSweeney (2006). ${ }^{2}$ Denman et al. (2007). ${ }^{3}$ Koike and Kobayashi (2001). 
Table 4. Effects of AOC and HMB on in vitro GP and MCP at $24 \mathrm{~h}$ incubation for different roughage sources

\begin{tabular}{|c|c|c|c|c|c|c|c|c|}
\hline Roughage & $\begin{array}{l}\mathrm{HMB} \\
(\mathrm{mg})\end{array}$ & $\begin{array}{l}\mathrm{AOC} \\
(\mathrm{mg})\end{array}$ & $\mathrm{pH}$ & $\begin{array}{l}\text { GP } \\
(\mathrm{mL})\end{array}$ & $\begin{array}{c}\mathrm{c} \\
(\% / \mathrm{h})\end{array}$ & $\begin{array}{c}\text { IVOMD } \\
(\%)\end{array}$ & $\begin{array}{c}\text { Ammonia-N } \\
(\mathrm{mg} / \mathrm{dL})\end{array}$ & $\begin{array}{c}\mathrm{MCP} \\
(\mathrm{mg} / \mathrm{mL})\end{array}$ \\
\hline \multirow[t]{6}{*}{$\overline{\mathrm{CWR}}$} & 0 & 0 & 6.68 & 45.9 & 6.96 & 61.1 & 29.3 & 1.22 \\
\hline & & 3 & 6.66 & 49.5 & 7.90 & 64.6 & 29.0 & 1.35 \\
\hline & & 6 & 6.65 & 49.8 & 8.29 & 64.9 & 29.0 & 1.21 \\
\hline & 15 & 0 & 6.65 & 50.8 & 8.35 & 65.9 & 27.9 & 1.36 \\
\hline & & 3 & 6.66 & 52.6 & 8.54 & 67.7 & 27.9 & 1.38 \\
\hline & & 6 & 6.65 & 53.8 & 8.65 & 68.9 & 28.4 & 1.29 \\
\hline \multirow[t]{6}{*}{$\mathrm{CS}$} & 0 & 0 & 6.62 & 57.1 & 9.42 & 72.9 & 29.2 & 1.07 \\
\hline & & 3 & 6.63 & 56.6 & 9.64 & 72.4 & 28.0 & 1.20 \\
\hline & & 6 & 6.62 & 57.9 & 9.65 & 73.7 & 26.9 & 1.28 \\
\hline & 15 & 0 & 6.62 & 56.3 & 8.86 & 72.2 & 27.3 & 1.19 \\
\hline & & 3 & 6.62 & 60.0 & 8.60 & 75.8 & 26.5 & 1.31 \\
\hline & & 6 & 6.62 & 59.1 & 9.85 & 74.9 & 27.4 & 1.25 \\
\hline \multicolumn{3}{|l|}{ Pooled SEM } & 0.007 & 0.42 & 0.180 & 0.40 & 0.42 & 0.015 \\
\hline \multicolumn{9}{|c|}{ Significance of effects ( $\mathrm{p}$-value) } \\
\hline \multicolumn{3}{|l|}{ Roughage } & $<0.01$ & $<0.01$ & $<0.01$ & $<0.01$ & $<0.01$ & $<0.01$ \\
\hline \multicolumn{3}{|l|}{ HMB } & 0.28 & $<0.01$ & 0.14 & $<0.01$ & $<0.01$ & $<0.01$ \\
\hline \multicolumn{3}{|l|}{$\mathrm{AOC}$} & 0.20 & $<0.01$ & $<0.01$ & $<0.01$ & 0.11 & $<0.01$ \\
\hline \multirow[t]{2}{*}{ AOC } & Linear & & 0.12 & $<0.01$ & $<0.01$ & $<0.01$ & 0.08 & $<0.01$ \\
\hline & Quadratic & & 0.37 & $<0.01$ & 0.45 & $<0.01$ & 0.23 & $<0.01$ \\
\hline \multicolumn{3}{|c|}{ Roughage $\times \mathrm{HMB}$} & 0.72 & $<0.01$ & $<0.01$ & $<0.01$ & 0.99 & 0.38 \\
\hline \multicolumn{3}{|c|}{ Roughage $\times \mathrm{AOC}$} & 0.66 & 0.03 & 0.09 & 0.03 & 0.14 & $<0.01$ \\
\hline \multicolumn{3}{|c|}{$\mathrm{HMB} \times \mathrm{AOC}$} & 0.13 & 0.16 & 0.07 & 0.15 & 0.04 & $<0.01$ \\
\hline \multicolumn{3}{|c|}{ Roughage $\times \mathrm{HMB} \times \mathrm{AOC}$} & 0.06 & 0.02 & $<0.01$ & $<0.01$ & 0.36 & $<0.01$ \\
\hline
\end{tabular}

$\mathrm{AOC}$, Aspergillus oryzae culture; $\mathrm{HMB}, 2$-hydroxy-4-(methylthio)-butanoic acid; GP, gas production; MCP, microbial protein; IVOMD, in vitro organic matter digestibility; c, rate constant of GP $(\% / \mathrm{h})$; CWR, Chinese wild rye; CS, corn silage; SEM, standard error of the mean.

$=0.04$ ) and MCP (linear, $\mathrm{p}<0.01$; quadratic, $\mathrm{p}<0.01$ ) were increased as AOC concentration increased. Ammonia-N was decreased in response to addition of $\mathrm{HMB}(\mathrm{p}<0.01)$ and AOC (linear, $\mathrm{p}<0.01$ ). The $\mathrm{HMB} \times \mathrm{AOC}$ interactions for $\mathrm{GP}$, c, IVOMD, ammonia-N and MCP were observed $(\mathrm{p} \leq 0.02)$.

\section{Volatile fatty acid}

Effects of HMB and AOC on total VFA and molar proportion of each fatty acid of two forages are presented in Table 5.

Chinese wild rye: Total VFA concentrations were significantly increased with the addition of HMB $(p<0.01)$ and AOC (linear, $\mathrm{p}<0.01$ ). Neither HMB nor AOC had a significant effect on molar proportions of acetate, propionate, butyrate and acetate/propionate $(\mathrm{A} / \mathrm{P})(\mathrm{p}>0.05)$. There was no interaction for $\mathrm{HMB}$ and $\mathrm{AOC}$ on VFA $(\mathrm{p}>0.05)$.

Corn silage: Adding HMB significantly increased total VFA $(p<0.01)$ and molar proportion of acetate $(p<0.01)$, but decreased molar proportion of butyrate $(p<0.01)$. Increases in total VFA (linear, $\mathrm{p}<0.01$; quadratic, $\mathrm{p}<0.01$ ), acetate (quadratic, $\mathrm{p}<0.01$ ), propionate (linear, $\mathrm{p}=0.04$; quadratic, $\mathrm{p}=0.02$ ) and decreases in butyrate (quadratic, $\mathrm{p}<0.01$ ) were noted as AOC concentration increased. The $\mathrm{HMB} \times \mathrm{AOC}$ interactions for total VFA, propionate, butyrate and $\mathrm{A} / \mathrm{P}$ were observed $(\mathrm{p} \leq 0.04)$.

\section{Rumen microbial population}

Microbial populations ( $\%$ of total bacterial $16 \mathrm{~S}$ rDNA) of two forages are given in Table 6.

Chinese wild rye: Adding HMB significantly increased protozoa percentage $(\mathrm{p}=0.03)$ and decreased fungi percentage $(\mathrm{p}=0.02)$ (Table 6$)$. However, supplementing AOC significantly decreased protozoa percentage (quadratic, $\mathrm{p}=0.01$ ) and increased fungi percentage (quadratic, $\mathrm{p}<0.01$ ). There was no significant effect of HMB on three kinds of fibrolytic bacteria $(p>0.05)$. Percentages of $F$. succinogenes, $R$. albus (linear, $\mathrm{p}<0.01$; quadratic, $\mathrm{p} \leq 0.02$ ) and $R$. flavefaciens (linear, $\mathrm{p}<0.01$ ) were increased in response to addition of AOC. There was an interaction between $\mathrm{HMB}$ and $\mathrm{AOC}$ for fungi and $R$. flavefaciens ( $\mathrm{p}<$ $0.01)$.

Corn silage: Protozoa population was significantly decreased $(\mathrm{p}=0.01)$, population of $F$. succinogenes and $R$. albus were markedly increased $(\mathrm{p} \leq 0.03)$ by adding HMB. Supplementing AOC significantly increased fungi (quadratic, $\mathrm{p}=0.02$ ), $F$. succinogenes (linear, $\mathrm{p}=0.02$ ) and $R$. flavefaciens (linear, $\mathrm{p}=0.02$ ). An interaction between 
Table 5. Effects of AOC and HMB on total VFA and individual VFA at $24 \mathrm{~h}$ incubation for different roughage sources

\begin{tabular}{|c|c|c|c|c|c|c|c|}
\hline \multirow{2}{*}{ Roughage } & \multirow{2}{*}{$\begin{array}{c}\text { HMB } \\
\text { (mg) }\end{array}$} & \multirow{2}{*}{$\begin{array}{l}\mathrm{AOC} \\
(\mathrm{mg})\end{array}$} & \multirow{2}{*}{$\begin{array}{l}\text { Total VFA } \\
(\mathrm{mmol} / \mathrm{L})\end{array}$} & \multicolumn{4}{|c|}{ Molar proportion $(\mathrm{mol} / 100 \mathrm{~mol})$} \\
\hline & & & & Acetate & Propionate & Butyrate & $\mathrm{A} / \mathrm{P}$ \\
\hline \multirow[t]{6}{*}{ CWR } & 0 & 0 & 71.0 & 66.7 & 19.7 & 13.6 & 3.39 \\
\hline & & 3 & 72.2 & 66.7 & 19.9 & 13.5 & 3.36 \\
\hline & & 6 & 72.7 & 66.7 & 19.3 & 14.0 & 3.45 \\
\hline & 15 & 0 & 73.4 & 66.8 & 19.2 & 14.0 & 3.48 \\
\hline & & 3 & 74.5 & 66.4 & 19.6 & 14.0 & 3.39 \\
\hline & & 6 & 75.6 & 66.7 & 19.3 & 14.1 & 3.46 \\
\hline \multirow[t]{6}{*}{ CS } & 0 & 0 & 80.8 & 64.9 & 20.9 & 14.2 & 3.11 \\
\hline & & 3 & 80.2 & 65.3 & 22.2 & 12.5 & 2.94 \\
\hline & & 6 & 81.1 & 64.5 & 22.0 & 13.5 & 2.93 \\
\hline & 15 & 0 & 80.1 & 65.4 & 22.0 & 12.6 & 2.98 \\
\hline & & 3 & 84.4 & 65.9 & 21.9 & 12.2 & 3.00 \\
\hline & & 6 & 82.4 & 65.1 & 21.6 & 13.2 & 3.01 \\
\hline \multicolumn{3}{|l|}{ Pooled SEM } & 0.33 & 0.21 & 0.24 & 0.25 & 0.044 \\
\hline \multicolumn{8}{|c|}{ Significance of effects ( $\mathrm{p}$-value) } \\
\hline \multicolumn{3}{|l|}{ Roughage } & $<0.01$ & $<0.01$ & $<0.01$ & $<0.01$ & $<0.01$ \\
\hline \multicolumn{3}{|l|}{ HMB } & $<0.01$ & 0.04 & 0.66 & 0.20 & 0.33 \\
\hline \multicolumn{3}{|l|}{$\mathrm{AOC}$} & $<0.01$ & 0.12 & 0.03 & $<0.01$ & 0.12 \\
\hline \multirow[t]{2}{*}{$\mathrm{AOC}$} & Linear & & $<0.01$ & 0.19 & 0.46 & 0.73 & 0.42 \\
\hline & Quadratic & & $<0.01$ & 0.10 & 0.01 & $<0.01$ & 0.06 \\
\hline \multicolumn{3}{|c|}{ Roughage $\times$ HMB } & 0.02 & 0.02 & 0.16 & $<0.01$ & 0.44 \\
\hline \multicolumn{3}{|c|}{ Roughage $\times$ AOC } & 0.04 & 0.04 & 0.27 & 0.03 & 0.30 \\
\hline \multicolumn{3}{|c|}{$\mathrm{HMB} \times \mathrm{AOC}$} & $<0.01$ & 0.53 & 0.20 & 0.12 & 0.48 \\
\hline \multicolumn{3}{|c|}{ Roughage $\times \mathrm{HMB} \times \mathrm{AOC}$} & $<0.01$ & 0.90 & 0.02 & 0.09 & 0.04 \\
\hline
\end{tabular}

AOC, Aspergillus oryzae culture; HMB, 2-hydroxy-4-(methylthio)-butanoic acid; VFA, volatile fatty acid; A/P, acetate/propionate; CWR, Chinese wild rye; CS, corn silage; SEM, standard error of the mean.

HMB and AOC for R. albus was observed ( $\mathrm{p}=0.04)$.

\section{DISCUSSION}

\section{In vitro gas production and microbial protein}

The $\mathrm{pH}$, GP, ammonia-N and $\mathrm{MCP}$ are important parameters reflecting ruminal environment. In the current study, terminal $\mathrm{pH}$ of two roughage sources was not influenced by $\mathrm{HMB}$ and $\mathrm{AOC}$ and all $\mathrm{pHs}$ were within the normal range. Addition of AOC and HMB caused marked increases of GP, IVOMD, and MCP which meant the two additives promoted rumen fermentations. The responses to AOC were very similar to the results of Lee et al. (2004) who found the addition of anaerobic fungal culture caused a marked increase in GP, cellulose digestion and bacterial population. There are few reports of $\mathrm{HMB}$ on GP in the in vitro test. In addition, for $\mathrm{CS}$ there were $\mathrm{HMB} \times \mathrm{AOC}$ interactions in GP and IVOMD which meant that the two additives interacted with each other and showed that adding HMB and AOC simultaneously to CS had a significant effect on GP and IVOMD.

Ammonia concentration in the rumen is a balance between degradation of feed protein and uptake of ammonia for synthesis of microbial protein. Ammonia-N decreasing effect was only shown with HMB for CWR, which means HMB was more efficient than AOC in MCP production and a part of HMB seemed to be efficiently utilized as a nitrogen source. This finding is consistent with the result of Jouany et al. (1998), who reported that adding AOC had no effect on in vitro ammonia-N. The result with HMB agreed with the report of Vázquez-Añón et al. (2001), who found that addition of HMB in the feed improved microbial protein synthesis and reduced rumen ammonia-N. However, both AOC and HMB reduced ammonia-N and enhanced MCP for CS. In addition, a $\mathrm{HMB} \times \mathrm{AOC}$ interaction in MCP for the two roughages was observed. The reason for a different effect of AOC on ammonia-N of CWR and CS is not clear. This phenomenon was also further enhanced by a larger $\mathrm{HMB} \times \mathrm{AOC}$ effect on $\mathrm{CS}$ ammonia-N. The reason for this difference may be due to the high nitrogen content of CS.

\section{Volatile fatty acid}

VFA is the product of microbial fermentation of carbohydrates in the rumen; therefore, increased ruminal VFA concentrations are often assumed to be a result of this fermentation. From our study, total VFA of CWR and CS was increased by supplementing AOC and HMB. 
Table 6. Effects of AOC and HMB on microbial populations (\% of total bacterial 16S rDNA) for different roughage sources



Frumholtz et al. (1989) reported the addition of AOC resulted in an increase of total VFA. Martin et al. (2013) showed HMB and isopropyl ester of HMB (HMBi) supplementation increased VFA concentrations in the rumen. However, Whelan et al. (2013) showed supplementary HMBi had no effect on rumen $\mathrm{pH}$, VFA or ammonia-N in lactating dairy cows offered a low crude protein diet. Though both HMB and AOC increased total VFA, their effects on molar proportions of each VFA were different with the two roughage sources. That different fermentation patterns were shown by the two forages was probably due to their different chemical compositions. As shown in Table 1, CS had more protein, less organic matter, NDF and ADF than CWR which led to its easily being digested by microbes in the rumen. Noftsger et al. (2003) showed supplementation of HMB did not affect total VFA but observed differences in concentration of individual VFA which was different from our findings. In addition, AOC showed better effect on propionate feasibly due to enhanced soluble carbohydrate digestion by its $\alpha$-amylase. This finding was inconsistent with Carton et al. (1993), who concluded supplemental AOC did not affect total VFA and VFA proportions. There were $\mathrm{HMB} \times \mathrm{AOC}$ interactions in total VFA for CS. In combination, the two additives had significant effects on total VFA.

\section{Rumen microbial population}

In the current study, adding $\mathrm{HMB}$ and $\mathrm{AOC}$ had different effects on protozoa and fungi. Despite HMB supplementation significantly enhancing GP and total VFA of CWR, it did not increase the population of three cellulolytic species. An increase of $F$. succinogenes and $R$. albus was only observed with HMB for CS. Blake et al. (1986) suggested that HMB might stimulate a more metabolically active bacterial population. Martin et al. (2013) reported HMB supplementation had no effect on the total protozoa concentration, increased rumimal abundance of $F$. succinogenes and $R$. flavefaciens, but did not improve rumen fibrolytic activity. Supplementing AOC significantly increased the populations of fungi and $F$. succinogenes in the two roughage sources. In addition, AOC only significantly increased $R$. albus in CWR compared with CS because CWR had a greater amount of fiber substrate to act upon. It may be that these results are related to the NDF and/or starch proportion of the substrates. Although AOC does not produce the enzymatic machinery to completely depolymerize structural carbohydrates to simple sugars, it does produce enzymes that cause partial depolymerization 
(Boing, 1983) and it aids rumen cellulytic bacteria in completing the depolymerization of cellulosic material to simple sugars (Autrey et al., 1975). Newbold (1997) also presented data indicating that AOC stimulated the attachment of rumen microbes to plant fiber, which may explain how small quantities of fungi can have a significant effect on fiber degradation. In addition, there were interactions between HMB and AOC in fungi and $R$. flavefaciens of CWR and in R. albus of CS. The larger $\mathrm{HMB} \times \mathrm{AOC}$ effects on fungi and $R$. flavefaciens with AOC could partly be explained by Schmidt et al. (2004) who found that AOC accelerated the production and maturation of zoospores of Neocallimastix frontalis EB 188, along with an elevated production of protein and carboxymethy cellulase (CMCase). The mechanisms by which these supplements could impact microbial digestion in the rumen have not yet to be clarified. Nevertheless further research is warranted to understand their exact mode of action.

\section{CONCLUSION}

Results of this study suggest that addition of HMB and AOC had significant effect on GP, MCP, and total VFA of CWR and CS. However, as AOC affected the populations of fungi, $F$. succinogenes and $R$. flavefaciens in both roughages, HMB influenced $F$. succinogenes and $R$. albus only in CS. The HMB by AOC interactions were significant in MCP and total VFA which might be caused by collaboration of fungi, $R$. albus and $R$. flavefaciens.

\section{ACKNOWLEDGMENTS}

This work was supported by grants from National Key Basic Research Program of China (No. 2011CB100801), Novus International Inc. and the China Agriculture Research System (CARS-37).

\section{REFERENCES}

AOAC. 1997. Official Methods of Analysis, 16th ed. Association of Official Analytical Chemists, Arlington, VA, USA.

Autrey, K. M., J. A. McCaskey, and J. A. Little. 1975. Cellulose digestibility of fibrous materials treated with Trichoderma viride cellulase. J. Dairy Sci. 58:67-71.

Beharka, A. A. and T. G. Nagaraja. 1993. Effect of Aspergillus oryzae fermentation extract $\left(\right.$ Amaferm $\left.{ }^{\circledR}\right)$ on in vitro fiber degradation. J. Dairy Sci. 76:812-818.

Blake, W. L., M. D. Stern, and S. M. Hannah. 1986. Effect of supplementing methionine in various forms on bacterial degradation of methionine in continuous culture. Nutr. Rep. Int. 33:729-738.

Boing, J. T. P. 1983. Enzyme production. In: Industrial Microbiology (Ed. G. Reed). 4th ed. AVI Publ. Co., Inc., Westport, CT, USA. pp. 685-689.
Carton, J. S., D. O. Erickson, D. A. Carey, and D. L. Ulmer. 1993. Influence of Aspergillus oryzae fermentation extract on forage intake, site of digestion, in situ degradability, and duodenal amino acid flow in steers grazing cool-season pasture. J. Anim. Sci. 71:779-787.

Chen, C. R., B. Yu, and P. W. S. Chiou. 2004. Roughage energy and degradability estimation with Aspergillus oryzae inclusion using Daisy ${ }^{\circledR}$ in vitro fermentation. Asian Australas. J. Anim. Sci. 17:53-62.

Chen, X. L., J. K. Wang, Y. M. Wu, and J. X. Liu. 2008. Effects of chemical treatments of rice straw on rumen fermentation characteristics, fibrolytic enzyme activities and populations of liquid- and solid-associated ruminal microbes in vitro. Anim. Feed Sci. Technol. 141:1-14.

Chung, Y. H., H. G. Bateman, C. C. Williams, C. C. Stanley, D. T. Gantt, T. W. Braud, L. L. Southern, J. D. Ward, P. G. Hoyt, and G. A. Sod. 2006. Effects of methionine and lysine on fermentation in vitro and in vivo, nutrient flow to the intestine, and milk production. J. Dairy Sci. 89:1613-1620.

Denman, S. E. and C. S. McSweeney. 2006. Development of a real-time PCR assay for monitoring anaerobic fungal and cellulolytic bacterial populations within the rumen. FEMS Microbiol. Ecol. 58:572-582.

Denman, S. E., N. W. Tomkins, and C. S. McSweeney. 2007. Quantitation and diversity analysis of ruminal methanogenic populations in response to the antimethanogenic compound bromochloromethane. FEMS Microbiol. Ecol. 62:313-322.

Di Francia, A., F. Masucci, G. De Rosa, M. L. Varricchio, and V. Proto. 2008. Effects of Aspergillus oryzae extract and a Saccharomyces cerevisiae fermentation product on intake, body weight gain and digestibility in buffalo calves. Anim. Feed Sci. Technol. 140:67-77.

Frumholtz, P. P., C. J. Newbold, and R. J. Wallace. 1989. Influence of Aspergillus oryzae fermentation extract on the fermentation of a basal ration in the rumen simulation technique (Rusitec). J. Agric. Sci. (Camb.) 113:169-172.

Hu, W. L., J. X. Liu, J. A. Ye, Y. M. Wu, and Y. Q. Guo. 2005. Effects of tea saponin on rumen fermentation in vitro. Anim. Feed Sci. Technol. 120:333-339.

Jouany, J. P., F. Mathieu, J. Senaud, J. Bohatier, G. Bertin, and M. Mercier. 1998. Effect of Saccharomyces cerevisiae and Aspergillus oryzae on the digestion of nitrogen in the rumen of defaunated and refaunated sheep. Anim. Feed Sci. Technol. 75:1-13.

Koike, S. and Y. Kobayashi. 2001. Development and use of competitive PCR assays for the rumen cellulolytic bacteria: Fibrobacter succinogenes, Ruminococcus albus and Ruminococcus flavefacies. FEMS Microbiol. Lett. 204:361366.

Lee, S. S., C. K. Choi, B. H. Ahn, Y. H. Moon, C. H. Kim, and J. K. Ha. 2004. In vitro stimulation of rumen microbial fermentation by a rumen anaerobic fungal culture. Anim. Feed Sci. Technol. 115:215-226.

Mao, H. L., J. K. Wang, Y. Y. Zhou, and J. X. Liu. 2010. Effect of addition of tea saponin and soybean oil on methane production, fermentation and microbial population in the rumen of growing lambs. Livest. Sci. 129:56-62.

Martin C., C. Mirande, D. P. Morgavi, E. Forano, E. Devillard, and 
P. Mosoni. 2013. Methionine analogues HMB and HMBi increase the abundance of cellulolytic bacterial representatives in the rumen of cattle with no direct effects on fibre degradation. Anim. Feed Sci. Technol. 182:16-24.

Menke, K. H. and H. Steingass. 1988. Estimation of the energetic feed value obtained from chemical analysis and in vitro gas production using rumen fluid. Anim. Res. Dev. 28:7-55.

National Research Council. 2001. Nutrient Requirements of Dairy Cattle. 7th rev. Edn. National Academy Press, Washington, DC, USA.

Newbold, J. 1997. Proposed mechanisms for enzymes as modifiers of ruminal fermentation. In: Processing of the 8th Annual Ruminant Nutrition Symposium, Gainesville, Florida, USA. pp. 146-159.

Noftsger, S. M., N. R. St-Pierre, S. K. R. Karnati, and J. L. Firkins. 2003. Effects of 2-hdyroxy-4-(methylthio) butanoic acid (HMB) on microbial growth in continuous culture. J. Dairy Sci. 86:2629-2636.

Ørskov, E. R. and I. McDonald. 1979. The estimation of protein degradability in the rumen from incubation measurements weighted according to rate of passage. J. Agric. Sci. (Camb.) 92:499-503.

SAS. 1999. SAS User's Guide: Statistics, Version 8.0. SAS Inst Inc, Cary, NC, USA.
Schmidt, J. A., S. Albright, G. M. Calza, and R. E. Calza. 2004. Characterization of Aspergillus oryzae fermentation extract effects on the rumen fungus Neocallimastix frontalis EB 188. Part 2. Carbon source utilization and effects on zoospore production. Appl. Microbiol. Biotechnol. 63:431-437.

Van Soest, P. J., J. B. Bobertson, and B. A. Lewis. 1991. Methods for dietary fiber, neutral detergent fiber and non-starch polysaccharides in relation to animal nutrition. J. Dairy Sci. 74:3583-3597.

Vázquez-Añón, M., T. Cassidy, P. McCullough, and G. A. Varga. 2001. Effects of Alimet on nutrient digestibility, bacterial protein synthesis, and ruminal disappearance during continuous culture. J. Dairy Sci. 84:159-166.

Wang, Y. and T. A. McAllister. 2002. Rumen microbes, enzymes and feed digestion-A review. Asian Australas. J. Anim. Sci. 15:1659-1676.

Whelan, S. J., F. J. Mulligan, J. J. Callan, B. Flynn, and K. M. Pierce. 2013. Effect of forage source and a supplementary methionine hydroxyl analogue on rumen fermentation parameters in lactating dairy cows offered a low crude protein diet. Anim. Feed Sci. Technol. 183:62-66.

Wilson, K. R., C. S. Abney, J. T. Vasconcelos, M. Vázquez-Añón, J. P. McMeniman, and M. L. Galyean. 2008. Effects of 2hydroxy-4-(methylthio)-butanoic acid on performance and carcass characteristics of finishing beef cattle and on fermentation in continuous culture. J. Anim. Sci. 86:1951-1962. 